\title{
Audit Research Summaries
}

Hierbij weer enkele "Audit Research Summaries" uit de database van de American Accounting Association (www.auditingresearchsummaries.org).

Deze keer illustreren wij een drietal samenvattingen die betrekking hebben op "Audit Team Composition" (Topics 05.0) die in de database als volgt zijn onderverdeeld ${ }^{1}$ :

- 05.01 Use of Specialists e.g., financial instruments, actuaries, valuation

- 05.02 Industry Expertise - Firm and Individual

- 05.03 Partner Rotation

- 05.04 Staff Hiring, Turnover and Morale

- 05.05 Diversity of Skill Sets e.g., Tenure and Experience

- 05.06 Qualifications of Engagement Quality Reviewers

- 05.07 Impact of 150-hour requirement

- 05.08 Impact of Office Size

- 05.09 Group Decision-Making

- 05.10 Impact of Diversity - e.g., gender - on Group Decision Making

De eerste samenvatting betreft de studie "Group judgment and decision making in auditing: Past and future research". De studie verschaft een mooi overzicht van onderzoek naar de effecten van het interne review proces, brainstorming en consultatie binnen het kantoor, dat in de periode 1970-2015 in een aantal vooraanstaande vaktijdschriften is verschenen.

"When You Make Manager, We Put A Big Mountain in Front Of You" is de intrigerende titel van een onderzoek uitgevoerd door Kornberger et al, 2011. Het onderzoek gaat in op de wijze waarop managers in een complex netwerk van interacties een balans zoeken tussen het zijn van een goede team- en time/budget manager en het onderhouden van zowel relaties met junior teamleden, partner en klant. Opmerkelijk is de noodzaak dat managers zichtbaar zijn in de accountantsorganisatie, in het artikel aangeduid met het ontwikkelen van een "fame agenda".

De laatste samenvatting is getiteld "Effects of Differences in National Culture on Auditors' Judgements and Decisions: A Literature Review of Cross Cultural Auditing Studies from a Judgment and Decision Making Perspective”. Deze studie geeft inzicht in onderzoek naar relevante "cross cultural" auditing onderzoeken die in de periode 19942014 zijn verschenen. Hierbij is een relatie gelegd met belangrijke onderzoeken op het terrein van oordeelsen besluitvorming in de psychologie. Een van de interessante bevindingen luidt dat in geval van conflicten personen uit een oosterse cultuur eerder geneigd zijn zwijgend met klanten en leidinggevenden in te stemmen, dan personen uit een westerse cultuur.

Het onderzoeksgebied "Audit Team Composition" wordt door de Foundation for Auditing Research relevant als volgt omschreven: "Audit inputs, such as audit team composition and interaction, the personal characteristics of audit partners and staff, their workload, and the knowledge, skills, and experience of auditors in relation to the complexity and context of the audits they are currently performing." (FAR, http:/www.foundationforauditingresearch.org). 
Title:

Practical Implications:
Group judgment and decision making in auditing: Past and future research

The insights highlighted in this paper from research on audit groups/teams inform one's understanding of how best to design group interactions between auditors within the firm and with professionals outside the audit firm, including management, audit committees, and inspectors.

These insights are important given the criticism audit firms have faced from regulators and inspectors over the past decade and the multi-person setting present in auditing. Further, while a large literature exists on single-person decision-making, these studies may not generalize to multi- person settings. The review also highlights the need for continued research in this area and the importance audit practitioner involvement with future research efforts.

\begin{tabular}{l|l} 
Citation: & Trotman, K., T. Bauer, and K. Humphreys. 2015. Group judgment and decision making in auditing: Past and future research. Ac-
\end{tabular} counting, Organizations and Society 47: 56-72.

\section{Keywords:}

Purpose of the

Study:

Review process, brainstorming, consultation

This paper examines experimental research on audit groups/teams. The paper focuses on three main areas: 1) the hierarchical review process, 2) brainstorming as part of the fraud detection planning process, and 3) consultation within firms. The authors define research on audit groups/team as those papers where two or more individuals within the audit firm interact with one another face-to-face, electronically, or where on person prepares/reviews working papers for another. In addition to summarizing research to date in each of the three areas, the authors suggest directions for future research within the three areas as well as future research on within-firm group interactions. These areas include shared mental models, audit team diversity, and interactions with groups outside the audit firm, such as audit committees.

Design/Method/ The paper summarizes research on group audit JDM experimental studies published in Accounting, Organization SocieApproach: ty, Contemporary Accounting Research, Journal of Accounting Research, and The Accounting Review from 1970 through 2015. Relevant working papers are also discussed.

Findings:

Note: Given the breadth of this review paper, only select subsections are summarized below.

- Hierarchical review process:

- What performance gains result from the review process?

- The review process generally improves audit effectiveness.

- However, it is not always effective as biases may not be mitigated by the review process, such as the recency effect.

- Alternative forms of the review process: Includes research on comparing reviews with and without discussion, specialized versus all-encompassing reviews, and electronic versus face-to-face reviews.

- Effects of the preparer on the review process:

- Studies investigate the attributes of the preparer and the effects of preparer stylization on the review process.

- Overall, preparer attributes and stylization have a significant impact on the review process.

- Brainstorming:

- Face-to-face interacting versus nominal brainstorming: Nominal groups generate more unique ideas than face-to-face interacting groups, due to process losses (e.g., production blocking) occurring in the face-to-face interacting context.

- Interacting face-to-face brainstorming compared to alternate brainstorming formats: While unstructured face-to-face brainstorming is the most common method used by audit firms, other methods (e.g., providing guidelines or instructions) outperform this unstructured method with respect to the quantity of fraud risks identified and fraud hypotheses generated.

- Electronic brainstorming:

- Positive consequences of electronic brainstorming include minimizing production blocking and evaluation apprehension, however social loafing is a potential negative consequence.

- Evidence supports the claim that electronic brainstorming is superior to face-to-face interaction, however as with non-electronic brainstorming, nominal electronic brainstorming outperforms interacting electronic brainstorming.

- Consultation within firms:

- Willingness to follow consulting advice: Auditors tend to incorporate advice received, however receiving advice can increase the tendency to follow aggressive client preferences.

- Willingness to seek consulting advice: In general, auditors are more likely and willing to consult when related risk is high.

\section{Overgenomen van www.auditingresearchsummaries.org, 28 maart 2016}


\begin{tabular}{l|l} 
Practical & This study points out the paradox that managers find themselves in as they struggle to manage relationships with staff, part-
\end{tabular} Implications: ners, and clients while simultaneously engaging in non-client productive activities in order to gain notoriety in the firm and impress the partners. The "mountain" referred to in the title of this article represents the different and unpredictable obstacles that managers must overcome in order to reach the other side of their career; partnership.

For more information on this study, please contact Martin Kornberger.

Citation: $\quad$ Kornberger, M., L. Justensen, and J. Mouritsen 2011. When you make manager, we put a big mountain in front of you: an ethnography of managers in a big 4 accounting firm. Accounting, Organizations and Society 36 (8): 514-533.

Purpose of the Study:
The "missing link" between trainee accountants and their senior employees, i.e. partners is the manager. This article suggests that becoming a manager is a rite of passage with two main effects:

- Destabilization of the manager's previous identity.

- Shaping of the new identity as a manager through a set of new practices.

The authors address the important, yet under-researched, role of the manager through an ethnographic analysis of their fundamental transition from junior trainees to potential partners in the context of a Big 4 Firm. This analysis outlines how managers in a complex network balance being an efficient client manager while also being a good team and time manager; additionally, how managers generate visibility to develop a "fame agenda" is addressed.

Design/Method/ Approach:
The authors collaborated with a Big 4 Firm to gather the data. The data consisted of four sources of empirical materials. First, the Big 4 Firm's website, newsletters, and other publicly accessible materials were analyzed along with confidential internal documents including employee satisfaction surveys, performance reports, change management surveys, exit surveys, and employment statistics. Second, the research team performed un-obtrusive on site observation including participating in meetings, planning sessions, client site visits, and other internal gatherings. Third, they conducted semi-structured interviews with $17 \mathrm{em}-$ ployees from different divisions of the organization and included partners, managers, and directors. Fourth, researchers shadowed 7 organizational members, managers and directors, for one working day each. The empirical research for this study was conducted between January 2005 and September 2006. However, a second round of interviews with senior executives was conducted from mid- 2009 until May 2010. An ethnographic approach was deemed the most appropriate method to allow researchers to focus on real data from many sources.

Findings:

- Managers must manage relationships with junior staff which involves acting as a mentor, a supervisor, a nurturer, and also as a person responsible for reviewing work and providing feedback.

- Managing client relationships is another key role for a manager. This role involves adjusting behavior towards the client according to the hierarchical position of the client representative as well as handling relationships with global and local clients differently. Relationships with higher ranked representatives and with local clients are more nurtured because of the increased influence that these clients have when deciding to keep the Big 4 Firm as the auditor. Additionally, managers have to find a way to use clients as a vehicle for self-promotion.

- Managers also have to be able to manage partner relationships. Managers must begin to show interests in different aspects of the firm to impress the partners who are ultimately responsible for the future of the managers. Managers must be able to handle the uncertainty that comes with a partner that can override any and all of a manager's decisions.

- However, one of the most important things that managers must be able to do has no technical relevance at all; it is to become visible to the firm. Managers must find time to get involved with firm initiatives in order to essentially gain popularity and increase their chances for promotion. This is referred to in the article as developing a "fame agenda". 


\begin{tabular}{|c|c|}
\hline Title: & $\begin{array}{l}\text { Effects of Differences in National Culture on Auditors' Judgments and Decisions: A Literature Review of Cross-Cultural Auditing } \\
\text { Studies from a Judgment and Decision Making Perspective }\end{array}$ \\
\hline $\begin{array}{l}\text { Practical } \\
\text { Implications: }\end{array}$ & $\begin{array}{l}\text { This study is important for audit firms because the authors imply that auditors' cross-cultural differences do not only depend on } \\
\text { which culture they come from, but also, on the national context of the countries in which the auditors reside (e.g., legal environ- } \\
\text { ment, auditing standards, tax issues) and other environmental factors (e.g., firm culture). By recognizing the effect of the social } \\
\text { environment and adopting a dynamic constructionist approach in future auditing research, cross-cultural variation of audi- } \\
\text { tors can be better understood, and audit firms will be better informed when designing intervention techniques to manage these } \\
\text { differences affecting audit quality. } \\
\text { For more information on this study, please contact Christine Nolder or Tracey J. Riley. }\end{array}$ \\
\hline Citation: & $\begin{array}{l}\text { Nolder, C. and T. J. Riley. 2014. Effects of Differences in National Culture on Auditors' Judgments and Decisions: A Literature } \\
\text { Review of Cross-Cultural Auditing Studies from a Judgment and Decision Making Perspective. Auditing: A Journal of Practi- } \\
\text { ce and Theory } 33 \text { (2): 141-164 }\end{array}$ \\
\hline Keywords: & Culture; ethics; risk; conflict; probability; bicultural; overconfidence; auditor judgment; diversity \\
\hline $\begin{array}{l}\text { Purpose of } \\
\text { the Study: }\end{array}$ & $\begin{array}{l}\text { In response to the shifting cultural makeup of audit staff and the importance of understanding its ultimate effect on audit quali- } \\
\text { ty, this paper summarizes the cross culture audit research and compares it with the broader cross-cultural judgment and decisi- } \\
\text { on making studies in psychology. To date, the cultural differences among auditors have not been fully understood, partially be- } \\
\text { cause researchers often rely on a somewhat outdated geographic trait approach. This approach assumes that each individual } \\
\text { auditor internalizes only one culture, and this culture has a predictable impact on auditors' judgments and decisions. The aut- } \\
\text { hors argue for a dynamic constructivist approach that recognizes that cross-cultural differences in judgments are heavily } \\
\text { dependent on environmental factors that elicit different motivational and cognitive responses depending on culture. } \\
\text { The authors also develop a framework that categorizes those auditor judgments and decisions most likely affected by cross- } \\
\text { cultural differences. The categories include: } \\
\text { - Auditors' confidence } \\
\text { - Risk and probability judgments } \\
\text { - Risk decisions } \\
\text { - Conflict decisions } \\
\text { - Ethical judgments }\end{array}$ \\
\hline $\begin{array}{l}\text { Design/Method/ } \\
\text { Approach: }\end{array}$ & $\begin{array}{l}\text { The authors discuss all relevant cross-cultural auditing studies from } 1994 \text { to } 2014 \text { in both auditing and accounting journals that } \\
\text { examine the five categories mentioned above and relate them to key studies in judgment and decision making research in psy- } \\
\text { chology. }\end{array}$ \\
\hline Findings: & $\begin{array}{l}\text { - While psychologists have found that Asians (with the exceptions of the Japanese) are more overconfident than Americans or } \\
\text { Europeans, no auditing researchers have examined cross-cultural differences in auditors' overconfidence. } \\
\text { - Psychologists, as well as most auditing researchers, have found evidence that supports the relationship between culture } \\
\text { and risk and probability judgments. } \\
\text { - Auditing researchers have found that auditors' risk decisions might vary significantly depending on cross-cultural differen- } \\
\text { ces, but they all rely on individual traits instead of environmental factors in the analyses as compared with psychologists. } \\
\text { - Auditing research that examines conflict decisions indicates that individuals from eastern cultures are more likely to acqui- } \\
\text { esce to clients and superiors than those from western cultures. This finding is consistent with psychological research. } \\
\text { - While psychologists pay little attention to cross-cultural differences in ethical judgments, three auditing researchers have } \\
\text { found some national differences and have emphasized the likely effect of task and environmental factors. } \\
\text { - Overall, the majority of auditing studies employ the trait approach, and thus fail to consider expatriates or bicultural audi- } \\
\text { tors' judgments and decisions. }\end{array}$ \\
\hline
\end{tabular}

Overgenomen van www.auditingresearchsummaries.org, 28 maart 2016 